\title{
Pengaruh Model Pembelajaran Auditory, Intellectually, Repetition Berbasis Brainstorming Terhadap Kompetensi Pengetahuan IPS
}

\author{
Ni Kd. Mia Widiastari ${ }^{1}$, Ni Wayan Suniasih ${ }^{2}$ \\ ${ }^{12}$ Prodi Pendidikan Guru Sekolah Dasar, FIP \\ Universitas Pendidikan Ganesha \\ Singaraja, Indonesia \\ e-mail: kadek.mia.widiastari@undiksha.ac.id ${ }^{1}$, niwayan.suniasih@undiksha.ac.id ${ }^{2}$
}

\begin{abstract}
Abstrak
Penelitian ini bertujuan untuk mengetahui pengaruh model pembelajaran Auditory, Intellectually, Repetition berbasis Brainstorming terhadap kompetensi pengetahuan IPS siswa kelas IV SD Gugus Letkol Wisnu. Jenis penelitian ini adalah eksperimen semu, dengan rancangan penelitian Non-Equivalent Control Group Design. Populasi dari penelitian ini adalah seluruh kelas IV di SD Gugus Letkol Wisnu yang berjumlah 327 siswa. Sampel diambil dengan teknik random sampling. Sampel dalam penelitian ini adalah kelas IV SD Negeri 5 Peguyangan sebanyak 30 siswa dan kelas IV SD Negeri 10 Peguyangan sebanyak 31 siswa. Metode pengumpulan data dalam penelitian ini menggunakan tes objektif. Data dianalisis dengan menggunakan uji-t. Hasil dari uji hipotesis diperoleh $t_{\text {hitung }}=4,250>t_{\text {tabel }}=2,000$ dengan $d k=59$ pada taraf signfikansi $5 \%$. Hal ini berarti terdapat perbedaan yang signifikan kompetensi pengetahuan IPS antara kelompok siswa yang dibelajarkan melalui model pembelajaran Auditory, Intellectually, Repetition berbasis Brainstorming dan kelompok siswa yang dibelajarkan menggunakan pembelajaran konvensional pada siswa kelas IV SD Gugus Letkol Wisnu Tahun Pelajaran 2018/2019. Rata-rata GSn kelompok eksperimen $\overline{X_{1}}=0,664>\overline{X_{2}}=$ 0,562 rata-rata GSn kompetensi pengetahuan IPS kelompok kontrol, sehingga dapat disimpulkan bahwa model pembelajaran Auditory, Intellectually, Repetition berbasis Brainstorming berpengaruh terhadap kompetensi pengetahuan IPS siswa kelas IV SD Gugus Letkol Wisnu.
\end{abstract}

Kata-kata kunci: auditory, intellectually, repetition, brainstorming, IPS

Abstract
The study aimed to determine the influence of Auditory, Intellectually, Repetition learning model-based Brainstorming on the IPS competency of fourth grade students SD Gugus Letkol Wisnu. This type of research is a pseudo experiment, with the design of Non-Equivalent Control Group Design Research. The population of this study is the entire fourth grade students in elementary school Letkol Wisnu, amounting to 327 students. Samples taken with random sampling techniques. The sample in this study was fourth grade students at SD Negeri 5 Peguyangan as many as 30 students and fourth grade students at SD Negeri 10 Peguyangan as many as 31 students. The method of collecting data in this study uses objective tests in the form of regular double choice. Data analyzed using t-test. The result of the hypothesis test was obtained $t_{\text {calculate }}=4.250>t_{\text {table }}=2,001$ with degree of freedom $=59$ at significancy level of $5 \%$. This means that there is a significant difference in the competency of the IPS knowledge between groups of students that are taught through the learning models of Auditory, Intellectually, and Brainstorming-based Repetition and groups of students who are taught using Conventional learning in fourth grade students elementary SD Gugus Letkol Wisnu in 2018/2019 Academic Year. Average GSn Group experiments $\overline{X_{1}}=0.664>\overline{X_{2}}=0.562$ average GSn knowledge competence IPS control group, so it can be concluded that the learning model Auditory, Intellectually, Repetition based Brainstorming affects the IPS competencies of fourth Grade Students at SD Gugus Letkol Wisnu.

Keywords: auditory, intellectually, repetition, brainstorming, IPS 


\section{Pendahuluan}

Pendidikan memiliki peran penting dalam upaya peningkatan sumber daya manusia ke arah yang lebih baik. Pendidikan yang berkualitas sangat diperlukan untuk mendukung terciptanya manusia yang cerdas serta mampu bersaing di masa mendatang. Pendidikan yang mampu mendukung pembangunan di masa mendatang adalah pendidikan yang mampu mengembangkan potensi peserta didik, sehingga peserta didik mampu menghadapi dan memecahkan problematika kehidupan yang dihadapi. Fungsi dan tujuan pendidikan terdapat dalam Undang- Undang No.20 Tahun 2003 Pasal 3 tentang Sistem Pendidikan Nasional yang menyatakan bahwa pendidikan nasional mengembangkan kemampuan dan membentuk watak serta peradaban bangsa yang bermartabat dalam rangka mencerdaskan kehidupan bangsa, bertujuan untuk berkembangnya potensi peserta didik agar menjadi manusia yang beriman dan bertakwa kepada Tuhan Yang Maha Esa, berakhlak mulia, sehat, berilmu, cakap, kreatif, mandiri, dan menjadi warga negara yang demokratis serta bertanggung jawab.

Salah satu unsur terpenting dari keberhasilan suatu tujuan pendidikan adalah kurikulum. Tujuan dari pendidikan dicapai dengan adanya kurikulum yang sesuai dan tepat. Kurikulum yang diterapkan saat ini yaitu kurikulum 2013. "Kurikulum 2013 bertujuan untuk mempersiapkan manusia Indonesia agar memiliki kemampuan hidup sebagai pribadi dan warga negara yang beriman, produktif, kreatif, inovatif, dan afektif serta mampu berkontribusi pada kehidupan bermasyarakat, berbangsa, bernegara dan peradaban dunia" (Rusman, 2015:92). Dalam kehidupan bermasyarakat sangat dibutuhkan suatu interaksi dan komunikasi untuk mewujudkan kehidupan sosial yang berlangsung dengan baik. Salah satu bentuk interaksi dan komunikasi di lingkungan sekolah yaitu dengan adanya diskusi untuk menuangkan ide-ide atau pendapat dari siswa. Hal tersebut sangat penting bagi siswa untuk mengembangkan potensinya dalam berfikir kritis dalam memecahkan masalah-masalah sosial yang ada di lingkungan sekitar siswa.

Ilmu yang mengkaji masalah sosial yang ada di masyarakat adalah IImu Pengetahuan Sosial (IPS). Menurut Susanto (2014) IPS adalah ilmu pengetahuan yang mengkaji berbagai disiplin ilmu sosial serta kegiatan dasar manusia dalam rangka memberi wawasan dan pemahaman yang mendalam kepada peserta didik, khususnya di tingkat dasar dan menengah terkait perkembangan dan permasalahan di lingkungan sosial. Menurut Gunawan (2013) hakikat IPS adalah telah tentang manusia dan dunianya sebagai makhluk sosial yang selalu hidup bersama, dengan adanya komunikasi antara satu orang dengan yang lainnya, antara negara satu dengan negara lainnya sehingga menguasasi berbagai informasi. Pentingnya peranan muatan materi IPS, seharusnya membuat IPS menjadi salah satu muatan materi yang menarik untuk dipelajari karena mencakup berbagai aspek kehidupan sosial, ekonomi, budaya, sejarah, dan sebagainya. Tetapi masih banyak siswa menganggap IPS sebagai suatu mata pelajaran yang membosankan dan sulit untuk dipahami.

Berdasarkan hasil observasi pada siswa kelas IV di SD Gugus Letkol Wisnu Kecamatan Denpasar Utara Tahun Pelajaran 2018/2019 dengan melakukan wawancara dari beberapa siswa dan wali kelas terkait mengenai kompetensi pengetahuan IPS siswa, maka diperoleh beberapa permasalahan yang ditemukan yaitu muatan materi IPS yang sering dikeluhkan karena banyak hafalan dan kurang menarik minat siswa dalam belajar sehingga sulit bagi siswa memahami konsep materi. Hal tersebut disebabkan karena muatan materi IPS yang dipelajari siswa kurang dikaitkan dengan fakta yang ada di lingkungan. Permasalahan lain yang muncul adalah kurangnya komunikasi dari siswa sehingga suasana kelas menjadi pasif, motivasi dalam diri siswa masih kurang untuk mengikuti pembelajaran, dan siswa belum terlibat langsung dengan pokok permasalahan yang diberikan karena tidak terbiasa dalam berfikir kritis, serta timbulnya rasa kurang percaya diri dalam mengemukakan ide atau pendapat terhadap suatu permasalahan.

Dari permasalahan tersebut, guru dapat membantu agar konsep-konsep penting dalam muatan materi IPS dapat tertanamkan kuat dalam pikiran siswa tersebut menggunakan model pembelajaran yang tepat, dengan mengutamakan peran siswa lebih banyak dari guru. Salah satu model pembelajaran yang menunjang kompetensi pengetahuan IPS siswa dan melatih siswa dalam berpikir kritis dan berkomunikasi adalah model pembelajaran Auditory, Intellectually, Repetition. Model pembelajaran ini terdiri dari tiga aspek yaitu auditory, intellectually, dan repetition. Pertama yaitu auditory, Shoimin (2014) menyatakan, "belajar bermodel auditory, yaitu belajar mengutamakan berbicara dan mendengarkan". Menurut Huda 
(2017), "auditorial adalah cara belajar untuk mengakses segala jenis bunyi dan kata, baik yang diciptakan maupun diingat yang mengandalkan pendengaran dan pembicaraan. Karena siswa yang auditoris lebih mudah belajar dengan cara berdiskusi dengan orang lain, maka guru sebaiknya melakukan hal-hal berikut: 1) Melaksanakan diskusi kelas atau debat, 2) Meminta siswa untuk presentasi, 3) Meminta siswa untuk membaca teks dengan keras, 4) Meminta siswa mendiskusikan ide mereka secara verbal, 5) Melaksanakan belajar kelompok". Jadi dapat disimpulkan bahwa, auditory merupakan cara belajar yang mengutamakan pendengaran dan berbicara melalui diskusi ide secara verbal sehingga memudahkan siswa dalam mengingat materi dalam jangka waktu yang lama.

Kedua yaitu Intellectually bermakna belajar haruslah menggunakan kemampuan berpikir, harus dengan konsentrasi pikiran dan berlatih menggunakannya melalui bernalar, menyelidiki, mengidentifikasi, menemukan, mencipta, mengonstruksi, memecahkan masalah, dan menerapkan. Aktifitas-aktfitas intelektual yang dapat melibatkan siswa dalam proses pembelajaran diantaranya, 1) memecahkan masalah, 2) menganalisis pengalaman, 3) mengerjakan perencanaan strategis, 4) melahirkan gagasan kreatif, 5) mencari dan menyaring informasi, 6) merumuskan pertanyaan, 7) menciptakan model mental, 8) menerapkan gagasan baru pada pekerjaan, 9) menciptakan makna pribadi, dan 10) meramalkan impikasi gagasan. Ketiga yaitu repetition atau pengulangan, dalam kegiatan pembelajaran dimaksudkan agar pemahaman siswa lebih mendalam, disertai pemberian soal dalam bentuk tugas latihan atau kuis. Dengan pemberian tugas, siswa lebih terlatih dalam menggunakan pengetahuan yang didapat dalam menyelesaikan soal dan mengingat apa yang telah diterima. Sementara dengan pemberian kuis dimaksudkan agar siswa siap menghadapi ujian atau tes yang dilaksanakan sewaktu-waktu serta melatih daya ingat. Sering kali siswa lupa dengan materi yang telah diterima, untuk itu dapat dibantu dengan mengulangi pelajaran yang telah dijelaskan.

Jadi dapat dirangkum bahwa model pembelajaran Auditory, Intellectually, Repetition ini dapat memudahkan siswa untuk mengingat lebih lama konsep materi yang diterima saat proses pembelajaran berlangsung dikarenakan model pembelajaran ini terdapat pengulangan materi berupa tugas atau kuis sehingga menimbulkan motivasi belajar dalam diri siswa, siswa terlibat langsung dalam pemecahan masalah dan dapat mengomunikasikannya hasil diskusi di depan teman-temannya yang dapat menimbulkan interaksi terhadap siswa lainnya, ditopang dengan brainstorming dalam kegiatan pembelajaran. Brainstorming menuntut siswa untuk aktif dalam pembelajaran. Brainstorming atau curah pendapat adalah suatu cara pengumpulan sejumlah besar gagasan dari sekelompok orang dalam waktu singkat (Ridwan, 2013).

Cara ini sering digunakan dalam pemecahan masalah yang kreatif dan dapat digunakan sendiri atau sebagai bagian dari strategi lain. Kegiatan curah pendapat sangat berguna untuk membangkitkan semangat belajar dan suasana meyenangkan ke dalam kegiatan kelompok, serta mengembangkan ide kreatif masing-masing peserta didik. Cara ini digunakan untuk menghasilkan sebanyak mungkin gagasan mengenai topik tertentu. Mukrimaa (2014) menyatakan keunggulan dari brainstorming yaitu : anak-anak berfikir untuk menyatakan pendapat, melatih siswa berpikir dengan cepat dan tersusun logis, merangsang siswa untuk selalu siap berpendapat yang berhubungan dengan masalah yang diberikan oleh guru, meningkatkan partisipasi siswa dalam menerima pelajaran, siswa yang kurang aktif mendapat bantuan dari temannya yang sudah pandai atau dari guru, Terjadi persaingan yang sehat, dan suasana demokratis dan disiplin dapat ditumbuhkan. Brainstorming memberikan kesempatan kepada siswa untuk menyampaikan pendapat dan menggunakan kemampuannya dalam memecahkan masalah, serta mampu menghargai pendapat orang lain. Proses pembelajaran menjadi lebih aktif dan memudahkan siswa dalam mengingat materi IPS karena siswa dituntut dalam berbicara dan mendengarkan

Berdasarkan uraian tersebut, maka dilakukan penelitian yang berjudul "Pengaruh Model Pembelajaran Auditory, Intellectually, Repetition Berbasis Brainstorming terhadap Kompetensi Pengetahuan IPS Siswa Kelas IV SD Gugus Letkol Wisnu Tahun Pelajaran 2018/2019". Tujuan penelitian ini adalah untuk Untuk mengetahui pengaruh Model Pembelajaran Auditory, Intellectually, Repetition Berbasis Brainstorming terhadap Kompetensi Pengetahuan IPS siswa kelas IV SD Gugus Letkol Wisnu Tahun Pelajaran 2018/2019. 


\section{Metode}

Penelitian ini dilaksanakan pada semester 2 tahun ajaran 2018/2019 di kelas IV SD Gugus Letkol Wisnu Denpasar Utara. Jenis penelitian yang digunakan adalah penelitian eksperimen yaitu quasi experiment design (eksperimen semu). Sugiyono (2016:114) memaparkan bahwa desain eksperimen semu (quasi experiment design) mempunyai kelompok kontrol tetapi tidak dapat befungsi sepenuhnya untuk mengontrol variabel-variabel luar yang memengaruhi pelaksanaan eksperimen. Subjek penelitian atau partisipan penelitian tidak dipilih secara acak untuk dilibatkan dalam kelompok eksperimen dan kelompok kontrol. Tujuan dari penelitian ini adalah untuk mengetahui pengaruh model pembelajaran Auditory, Intellectually, Repetition berbasis Brainstorming terhadap kompetensi pengetahuan IPS siswa kelas IV SD Gugus Letkol Wisnu Denpasar Utara.

Desain eksperimen semu yang digunakan dalam penelitian ini adalah Nonequivalent Control Group Design. Rancangan penelitian ini secara skematis dapat di gambarkan sebagai berikut.

\begin{tabular}{|cccc|}
\hline $\mathrm{O}_{1}$ & $\mathrm{X}$ & $\mathrm{O}_{2}$ & (eksperimen) \\
\hline $\mathrm{O}_{3}$ & & $\mathrm{O}_{4}$ & (kontrol) \\
\hline
\end{tabular}

Gambar 01 Rancangan penelitian non-equivalent control group design

(Sumber: Setyosari, 2015:211)

Keterangan:

$\mathrm{O} 1=$ pretest pada kelompok eksperimen

$\mathrm{O} 2$ = posttest pada kelompok eksperimen

$\mathrm{O} 3=$ pretest pada kelompok kontrol

$\mathrm{O} 4=$ posttest pada kelompok kontrol

$\mathrm{X}=$ Perlakuan yang diberikan pada kelompok eksperimen

Dalam rancangan penilitian non-equivalent control group design, ada dua kelompok subjek, satu kelompok mendapat perlakuan dan satu kelompok lagi sebagai kelompok kontrol. Sebelum pemberian perlakuan, dilakukan pengukuran awal atau pretest terhadap kedua kelompok tersebut. Selanjutnya, pada kelompok eksperimen diberikan perlakuan $(\mathrm{X})$ yaitu, model pembelajaran Auditory, Intellectually, Repetition berbasis Brainstorming, sedangkan untuk kelas kontrol dibelajarkan secara konvensional. Setelah itu, kedua kelompok dilakukan pengukuran pasca pemberian perlakuan atau postestt.

Pada tahapan persiapan eksperimen ini, kegiatan yang dilakukan oleh peneliti, yakni:1) Melakukan wawancara dengan kepala gugus Letkol Wisnu dan wali kelas IV di masing -masing sekolah di Gugus Letkol Wisnu untuk mengetahui ada atau tidaknya kelas unggulan di kelas IV di SD Gugus Letkol Wisnu. 2) Menyusun RPP (Rencana Pelaksanaan Pembelajaran) untuk kelas eksperimen dan kontrol, 3) Menyusun instrumen penelitian berupa tes kompetensi pengetahuan IPS siswa, 4) Mengkonsultasikan instrumen penelitian bersama wali kelas dosen pembimbing, 5) Mengkonsultasikan RPP bersama wali kelas dan dosen pembimbing, 6) Mengadakan validitas instrumen penelitian yaitu tes kompetensi pengetahuan IPS, 7) Menentukan sampel berupa kelas dari populasi dengan teknik random sampling.

Subjek yang diteliti diistilahkan sebagai populasi dan sampel. Dalam suatu penelitian populasi dan sampel memiliki hubungan yang saling keterkaitan. "Populasi merupakan keseluruhan dari objek, orang, peristiwa, atau sejenisnya yang menjadi perhatian dan kajian dalam penelitian" (Setyosari,2015:221). "Populasi diartikan wilayah generalisasi yang terdiri atas obyek/subyek yang mempunyai kualitas dan karakteristik tertentu yang ditetapkan oleh peneliti untuk dipelajari dan kemudian ditarik kesimpulannya" (Sugiyono, 2017:215). Jadi dapat disimpulkan pengertian populasi adalah kumpulan obyek/subyek, orang, peristiwa atau sejenisnya yang memiliki karakteristik tertentu yang ingin diteliti oleh peneliti lalu dipelajari dan ditarik kesimpulannya. 
Populasi dari penelitian ini adalah seluruh kelas IV SD Gugus Letkol Wisnu Denpasar Utara Tahun Pelajaran 2018/2019. Terdapat 7 (tujuh) SD Negeri di Gugus Letkol Wisnu Denpasar Utara, yaitu: SD N 1 Peguyangan, SD N 3 Peguyangan, SD N 5 Peguyangan, SD N 6 Peguyangan, SD N 10 Peguyangan, SD N 11 Peguyangan, dan SD N 12 Peguyangan. Jumlah populasi dari penelitian ini adalah 327 orang. Berdasarkan hasil wawancara yang dilakukan dengan ketua gugus, kepala sekolah, serta wali kelas IV dari 10 kelas yang ada di SD Gugus Letkol Wisnu diperoleh bahwa seluruh kelas setara secara akademik. Dikatakan setara karena pengelompokkan siswa ke dalam kelas-kelas dari 7 sekolah yang ada di SD Gugus Letkol di sebar secara merata antara siswa yang memiliki kemampuan tinggi, sedang, dan rendah. Dari keterangan tersebut tidak terdapat kelas unggulan maupun non unggulan. Pelaksanaan penelitian ini terdiri dari tiga tahapan yaitu, tahap persiapan eksperimen, tahap pelaksanaan eksperimen, dan tahap akhir eksperimen.

Pada tahap pelaksanaan eksperimen kegiatan yang ditempuh adalah : 1) Memberikan pre-test kepada kelompok eksperimen dan kelompok kontrol, 2)Melaksanakan penelitian yaitu memberikan perlakuan kepada kelompok eksperimen berupa model pembelajaran Auditory, Intellectually, Repetition berbasis Brainstorming, 3)Memberikan perlakukan pada pada kelas kontrol berupa pembelajaran konvensional, 4)Perlakuan diberikan sebanyak 6 kali di kelas eksperimen dan kelas kontrol. Saat tahap akhir eksperimen kegiatan yang ditempuh adalah : 1)Memberikan post-test pada akhir eksperimen, baik untuk kelompok eksperimen maupun kontrol, 2) Menganalisis data hasil penelitian, 3) Melakukan uji hipotesis.

Dari populasi yang telah ditentukan maka selanjutnya diambil perwakilan dari populasi tersebut yang dianggap mewakili seluruh populasi. Perwakilan dari populasi yang mewakili populasi disebut dengan sampel."Sampel adalah suatu kelompok yang lebih kecil atau bagian dari populasi secara keseluruhan" (Setyosari,2015:221). Dari populasi kelas IV SD Gugus Letkol Wisnu yang terdiri dari 10 kelas dipilih 2 kelas sebagai sampel penelitian, yaitu kelas eksperimen dan kelas kontrol. Untuk menentukan kelas eksperimen dan kelas kontrol teknik yang digunakan untuk pengambilan sampel pada penelitian ini adalah Random Sampling, yang di random kelasnya. Cara yang digunakan adalah dengan cara pengundian. "Pengambilan sampel dengan teknik random sampling dapat dilakukan dengan cara undian" (Agung, 2014:71). Langkah-langkah penentuan sampel adalah sebagai berikut.

Pada tahap pertama dilakukan teknik pengambilan sampel dengan cara undian, sehingga semua anggota populasi memiliki kesempatan yang sama untuk menjadi sampel penelitian. Cara undian dilakukan dengan menulis semua nama kelas IV di seluruh SD Gugus Letkol Wisnu, populasi pada masing-masing kertas yang jumlahnya 10 kemudian kertas digulung dan dimasukan ke dalam kotak dan dikocok untuk memilih dua kelas yang dijadikan sampel penelitian. Dua kelas yang muncul melalui pengundian kemudian diberikan pre-test. Setelah mengetahui bahwa kelas memiliki kesetaraan, kedua kelas yang telah diberi pre-test diundi kembali untuk menentukan kelompok eksperimen dan kelompok kontrol. Berdasarkan undian yang dilakukan, kelas IV SD Negeri 5 Peguyangan muncul pertama yang dijadikan sebagai kelas eksperimen sedangkan kelas IV SD Negeri 10 Peguyangan muncul pada undian kedua yang dijadikan sebagai kelompok kontrol.

Dalam penelitian ini data yang dianalisis adalah data kompetensi pengetahuan IPS pada siswa kelas IV SD Gugus Letkol Wisnu tahun Pelajaran 2018/2019 sebagai sampel. Untuk mendapatkan data tersebut digunakan metode tes. Tes merupakan alat atau prosedur yang digunakan untuk mengetahui atau mengukur sesuatu dalam suasana, dengan cara dan aturanaturan yang sudah ditentukan" (Arikunto, 2015:67). Tes kompetensi pengetahuan IPS yang digunakan dalam penelitian ini adalah tes objektif.

Instrumen pengumpulan data yang digunakan dalam penelitian ini adalah tes kompetensi pengetahuan IPS. Sebelum memberikan tes tersebut kepada siswa dilakukan pengujian untuk menguji kelayakan instrumen. Menurut Sugiyono (2017:102) "instrumen penelitian adalah suatu alat ukur yang digunakan dalam penelitian". Instrumen yang digunakan untuk mengumpulkan data kompetensi pengetahuan IPS adalah tes. "Tes merupakan alat atau prosedur yang digunakan untuk mengetahui atau mengukur sesuatu dalam suasana, dengan cara dan aturanaturan yang sudah ditentukan" (Arikunto, 2015:67). Tes yang baik harus mampu mengukur apa yang akan diukur (aspek validitas) dan konsisten atau stabil dalam mengukur apa yang akan diukur (aspek reliabilitas). Tes yang digunakan untuk mengukur kompetensi pengetahuan IPS siswa berupa tes objektif dalam bentuk pilihan ganda biasa dilakukan pengujian instrumen yaitu uji validitas, uji daya beda, uji indeks kesukaran, dan uji reliabilitas. Jumlah butir soal disusun berdasarkan kisi-kisi tes kompetensi pengetahuan IPS sebanyak 50 butir soal yang kemudian 
diujicobakan pada kelas yang jenjangnya lebih tinggi. Setelah dianalisis butir soal yang memenuhi syarat digunakan sebagai instrumen penelitian dengan jumlah 34 butir soal.

Setelah data dikumpulkan, data tersebut perlu dianalisis. Teknik analisis data yang digunakan untuk menganalisis data dalam penelitian ini adalah teknik analisis statistik inferensial. Pada penelitian ini sebelum analisis data melalui statistik inferensial dilakukan, terlebih dahulu hasil pre-test dan post-test pada kedua kelompok sampel dalam penelitian ini dinormalisasi dengan menggunakan gain skor ternormalisasi. adapun rumus gain skor ternormalisasi sebagai berikut.

$$
\text { GSn }=\frac{\text { Gain Skor }}{\text { Skor Max-Skor Pretest }}
$$

(Dantes, 2017:126)

Keterangan :

GSn = Gain skor ternormalisasi

Gain Skor $=$ Skor posttest-prestest

Dalam penelitian ini teknik analisis yang digunakan untuk menguji hipotesis menggunakan uji-t. Sebelum dilakukan uji-t, terlebih dahulu harus memenuhi uji prasyarat analisis, yaitu dengan uji normalitas sebaran data menggunakan uji Kolmogorov-Smirnov untuk mengetahui apakah sebaran data kompetensi pengetahuan IPS siswa masing-masing kelompok berdistribusi normal atau tidak sehingga dapat menentukan teknik analisis datanya. Uji normalitas sebaran data dilakukan pada kedua kelompok data yang meliputi data kelompok siswa yang dibelajarkan melalui model pembelajaran Auditory, Intellectually, Repetition berbasis Brainstorming dan data kelompok yang dibelajarkan secara konvensional. Kriteria pengujian adalah apabila nilai maksimum $\left|F_{\mathrm{T}}-\mathrm{F}_{\mathrm{S}}\right| \leq$ nilai tabel Kolmogorov-Smirnov, maka data berdistribusi normal. Setelah data berdistribusi normal, dilakukan uji homogenitas varians dengan uji fisher (uji F) untuk menunjukkan bahwa perbedaaan yang terjadi pada uji hipotesis benar-benar terjadi akibat adanya perbedaan antar kelompok, bukan sebagai akibat perbedaan dalam kelompok. Untuk mengetahui varian gabungan dengan menggunakan rumus varians terbesar diabgi varians terkecil. Kriteria pengujian untuk mengetahui data yang mempunyai varians yang homogen yaitu, jika nilai $F_{\text {hitung }} \leq$ nilai $F_{\text {tabel. }}$ Sedangkan jika $F_{\text {hitung }}>F_{\text {tabel, }}$ maka sampel dinyatakan tidak homogen. Pengujian dilakukan pada taraf signifikan $5 \%$ dengan derajat kebebasan untuk pembilang $n_{1}-1$ dan derajat kebebasan untuk penyebut $n_{2}-1$.

Data yang diperoleh sudah memenuhi prasyarat uji normalitas dan homogenitas maka analisis yang digunakan adalah statistik parametrik. Analisis statistik yang digunakan untuk menguji hipotesis penelitian ini adalah uji beda mean (uji-t). Uji Hipotesis menggunakan uji-t dengan rumus polled varians. Rumus uji-t dengan rumus polled varians digunakan bila jumlah anggota sampel sama $n_{1} \neq n_{2}$ dan varians homogen. Rumus uji-t dengan rumus polled varians sebagai berikut.

$$
t=\frac{\bar{X}_{1}-\bar{X}_{2}}{\sqrt{\frac{\left(n_{1}-1\right) s_{1}^{2}+\left(n_{2}-1\right) s_{2}^{2}}{n_{1}+n_{2}-2}\left(\frac{1}{n_{1}}+\frac{1}{n_{2}}\right)}}
$$

Keterangan :

$$
\begin{aligned}
& \bar{X}_{1}=\text { rata-rata nilai akhir kelompok eksperimen } \\
& \bar{X}_{2}=\text { rata-rata nilai akhir kelompok kontrol } \\
& S_{1}^{2}=\text { varian sampel kelompok eksperimen } \\
& S_{2}^{2}=\text { varian sampel kelompok kontrol } \\
& n_{1}=\text { jumlah siswa kelompok eksperimen } \\
& n_{2}=\text { jumlah siswa kelompok kontrol }
\end{aligned}
$$


Dengan kriteria pengujian, jika $t_{\text {hitung }}<t_{\text {tabel }}$, maka $\mathrm{H}_{\mathrm{o}}$ diterima dan $\mathrm{H}_{\mathrm{a}}$ ditolak, sebaliknya jika $t_{\text {hitung }} \geq \mathrm{t}_{\text {tabel }}$ maka $\mathrm{H}_{\mathrm{o}}$ ditolak dan $\mathrm{H}_{\mathrm{a}}$ diterima. Pada taraf signifikan $5 \%$ dengan dk $=\mathrm{n}_{1}+\mathrm{n}_{2}-$ 2 .

\section{Hasil dan Pembahasan}

Deskripsi data hasil penelitian ini memaparkan mengenai perolehan hasil post-test pada kelompok eksperimen dan kelompok kontrol di SD Gugus Letkol Wisnu Tahun Pelajaran 2018/2019. Data yang diperoleh dalam penelitian ini dikelompokan menjadi dua yaitu data kompetensi pengetahuan IPS siswa kelompok eksperimen di SD Negeri 5 Peguyangan dan data kompetensi pengetahuan IPS siswa kelompok kontrol di SD Negeri 10 Peguyangan.

Penelitian dilakukan sebanyak 6 kali perlakuan di kelas eksperimen yang menggunakan model pembelajaran Auditory, Intellectually, Repetition berbasis Brainstorming dan 6 kali pembelajaran pada kelas kontrol yang dibelajarkan secara konvensional. Pada akhir pertemuan diberikan post-test untuk memperoleh data kompetensi pengetahuan IPS siswa.

Setelah memperoleh skor post-test kemudian dicari gain skor ternormalisasi dari hasil pre-test dan post-test. Kemudian data dari gainskor tersebut dianalisis sehingga diperoleh mean $(\bar{X})$, standar deviasi $(\mathrm{s})$, varians $\left(\mathrm{s}^{2}\right)$. Rekapitulasi hasil perhitungan data post-test dapat dilihat pada tabel 01 .

Tabel 01.Deskripsi Rekapitulasi Data Gain Skor Kompetensi Pengetahuan IPS Kelompok Eksperimen dan Kelompok Kontrol

\begin{tabular}{ccc}
\hline Data & Kelompok Eksperimen & Kelompok Kontrol \\
\hline Mean & 0.664 & 0.562 \\
Standar Deviasi & 0.090 & 0.100 \\
Varians & 0.0081 & 0.010 \\
Skor Minimum & 0.52 & 0.30 \\
Skor Maksimum & 0.90 & 0.76
\end{tabular}

Berdasarkan nilai mean dari gain skor kelompok eksperimen yaitu $\bar{X}=0,664$ dengan standar deviasi 0,090 dan varians 0,0081 , sedangkan nilai mean dari gain skor kelompok kontrol yaitu $\bar{X}=0,562$ dengan standar deviasi 0,100 dan varians 0,010 . Dari hasil data perhitungan yang diperoleh, menunjukkan bahwa gain skor kompetensi pengetahuan siswa kelompok eksperimen yang mengikuti pembelajaran menggunakan model pembelajaran Auditory, Intellectually, Repetition berbasis Brainstorming memiliki nilai rata-rata lebih tinggi daripada kelompok kontrol.

Berdasarkan perhitungan hasil uji normalitas sebaran data gain skor siswa di kelas Eksperimen, diperoleh nilai maksimum $|F T-F S|=0,110$ sedangkan untuk nilai tabel Kolmogorov-Smirnov $(\alpha=0,05)=0,242$ karena Nilai tabel Kolmogorov-Smirnov $(\alpha=0,05)=$ $0,242>$ nilai maksimum $|F T-F S|=0,110$ maka sebaran data gain skor pada kelompok eksperimen berdistribusi normal. Berdasarkan perhitungan hasil uji normalitas sebaran data gain skor siswa di kelas Kontrol, diperoleh nilai maksimum $|F T-F S|=0,086$ sedangkan untuk nilai tabel Kolmogorov-Smirnov $(\alpha=0,05)=0,238$ karena nilai tabel Kolmogorov-Smirnov $(\alpha=$ $0,05)=0,238>$ nilai maksimum $|F T-F S|=0,086$ maka sebaran data gain skor siswa kelompok kontrol berdistribusi normal.

Setelah data diuji normalitas dan dinyatakan berdistribusi normal, kemudian dilanjutkan dengan uji homogenitas varians. Berdasarkan hasil analisis diperoleh diperoleh $F_{\text {hitung }}=1,239$ sedangkan untuk taraf signifikansi $5 \% \mathrm{~F}_{\text {tabel }}$ dengan dk pembilang 31-1 = 30 dan dk penyebut 30-1 = 29 adalah 1,85. Ini berarti $F_{\text {hitung }}=1,239<F_{\text {tabel }}=1,85$ maka data memiliki varians yang homogen. Berdasarkan hasil uji normalitas dan homogenitas dapat diketahui bahwa data yang diperoleh dari kelompok eksperimen dan kelompok kontrol berdistribusi normal dan memiliki varians yang homogen. Karena data yang diperoleh telah memenuhi semua prasyarat, uji hipotesis dilakukan dengan menggunakan analisis uji-t. Adapun kriteria pengujiannya adalah apabila $t_{\text {hitung }}<t_{\text {tabel }}$ maka $H_{0}$ diterima. Sebaliknya apabila $t_{\text {hitung }} \geq t_{\text {tabel, }}$, maka $H_{0}$ ditolak. Dengan 
dk $\mathrm{n}_{1}+\mathrm{n}_{2}-2$ dan taraf signifikansi $5 \%(\alpha=0,05)$. Hipotesis yang diuji dalam penelitian ini adalah tidak terdapat perbedaan yang signifikan kompetensi pengetahuan IPS siswa yang dibelajarkan menggunakan model Auditory, Intelectually, Repetition berbasis Brainstorming dan siswa yang dibelajarkan secara konvensional pada siswa kelas IV SD Gugus Letkol Wisnu Tahun Pelajaran 2018/2019.

Tabel 02. Rekapitulasi Hasil Analisis Uji-t Kelompok Sampel Penelitian

\begin{tabular}{lccccccc}
\hline Sampel Penelitian & $\mathbf{N}$ & $\mathbf{d k}$ & $\bar{x}$ & $\mathbf{s}^{2}$ & $\mathbf{t}_{\text {hitung }}$ & $\mathbf{t}_{\text {tabel }}$ & Keterangan \\
\hline $\begin{array}{l}\text { Kelompok } \\
\text { Eksperimen }\end{array}$ & 30 & & 0.664 & 0.081 & & & \\
$\quad$ Kelompok Kontrol & 31 & & 0.562 & 0.010 & & 1 & $\mathrm{H}_{\circ}$ Ditolak \\
& & & & & & &
\end{tabular}

Berdasarkan hasil analisis menggunakan uji-t diperoleh $t_{\text {hitung }}=4,250$. Kemudian dibandingkan dengan $t_{\text {tabel }}$ dengan $\mathrm{dk}=30+31-2=59$ pada taraf signifikansi $5 \%$ diperoleh $\mathrm{t}_{\text {tabel }}=$ 2,001 . Karena $t_{\text {hitung }}=4,250>t_{\text {tabel }}(\alpha=0,05)=2,001$, maka dapat disimpulkan bahwa terdapat perbedaan yang signifikan kompetensi pengetahuan IPS siswa yang dibelajarkan menggunakan model Auditory, Intelectually, Repetition berbasis Brainstorming dan siswa yang dibelajarkan menggunakan pembelajaran konvensional pada siswa kelas IV SD Gugus Letkol Wisnu Denpasar Utara Tahun Ajaran 2018/2019.

Rata-rata gain skor kompetensi pengetahuan IPS siswa kelas IV SD Negeri 5 Peguyangan pada kelompok eksperimen yaitu 0,664. Rata-rata gain skor kompetensi pengetahuan IPS siswa kelas IV SD Negeri 10 Peguyangan pada kelompok kontrol yaitu 0,562. Namun dilihat dari rata-rata gain skor yang diperoleh bahwa siswa pada kelompok eksperimen $\overline{X_{1}}=0,664>\overline{X_{2}}=0,562$ siswa pada kelompok kontrol. Hal ini berarti kelompok yang diberikan perlakuan dengan menggunakan model pembelajaran Auditory, Intellectually, Repetition berbasis Brainstorming berpengaruh terhadap kompetensi pengetahuan IPS pada siswa kelas IV SD Gugus Letkol Wisnu tahun pelajaran 2018/2019.

Dengan demikian, model pembelajaran Auditory, Intellectually, Repetition berbasis Brainstorming dapat direkomendasikan dalam membelajarkan siswa khususnya pada muatan materi IPS. Kegiatan pembelajaran menggunakan model pembelajaran Auditory, Intellectually, Repetition berbasis Brainstorming yang dilaksanakan di kelas eksperimen menunjukkan bahwa siswa dapat memperdalam pemahamannya mengenai materi pembelajaran, siswa dapat mengembangkan rasa ingin tahu, meningkatkan rasa percaya diri dalam menyampaikan pendapatnya, dan mengembangkan rasa saling bekerjasama antar siswa. Berbeda dengan kelompok kontrol yang melaksanakan pembelajaran secara konvensional, dalam kegiatan pembelajaran siswa lebih cepat bosan karena terlalu memuat banyak materi dan kurang melibatkan keaktifan siswa dalam proses pembelajaran.

Model Pembelajaran Auditory, Intellectually, Repetition adalah suatu model pembelajaran yang menekankan pada keaktifan siswa membangun pengetahuannya dengan pemecahan masalah baik secara individu maupaun kelompok. Proses pembelajaran dengan menggunakan model pembelajaran Auditory, Intellectually, Repetition berbasis Brainstorming yang memberikan permasalahan-permasalahan yang ada di kehidupan siswa bertujuan untuk mengembangkan kemampuan berpikir siswa untuk mendapat pemecahan masalah yang lebih luas dan mengasah kemampuan berpikir kreatif siswa, sehingga siswa lebih terbiasa dalam mengemukakan pendapat dari hasil pemikirannya.

Dengan menggunakan model Auditory, Intellectually, Repetition siswa dapat mengingat informasi lebih mudah. Adapun kelebihan model pembelajaran ini menurut Shoimin (2016:30), yaitu: (1) Siswa lebih berpartisipasi aktif dan sering mengekspresikan idenya, (2) Siswa memiliki kesempatan lebih banyak dalam memanfaatkan pengetahuannya (3) Siswa termotivasi untuk memberikan penjelasan. Sedangkan kelebihan dari Brainstorming antara lain anak-anak berfikir untuk menyatakan pendapat, melatih siswa berpikir dengan cepat dan tersusun logis, merangsang siswa untuk selalu siap berpendapat yang berhubungan dengan masalah yang diberikan oleh guru, meningkatkan partisipasi siswa dalam menerima pelajaran, terjadi persaingan yang sehat, anak merasa bebas dan gembira, suasana demokratis dan disiplin dapat ditumbuhkan. 
Hasil penelitian ini didukung pula oleh Yuni (2014) yang menyatakan bahwa terdapat perbedaan yang signifikan antara siswa yang mengikuti pembelajaran menggunakan model pembelajaran Auditory, Intellectually, Repetition dengan siswa yang mengikuti pembelajaran menggunakan metode pembelajaran konvensional pada siswa kelas VI. Penelitian lain yang mendukung yaitu dengan model pembelajaran berbasis brainstorming yaitu oleh Anggi Pratiwi (2014) yang menyatakan bahwa, terdapat pengaruh kelompok siswa yang dibelajarkan dengan model pembelajaran problem solving dan reasoning berbasis brainstorming.

Pemilihan model pembelajaran yang tepat dapat berpengaruh terhadap kompetensi pengetahuan IPS siswa. Penelitian ini membuktikan bahwa model pembelajaran Auditory, Intellectually, Repetition berbasis Brainstorming baik diterapkan dalam proses pembelajaran sebagai upaya perbaikan kompetensi pengetahuan IPS siswa. Hal ini dapat dilhat dari perbedaan rata-rata kompetensi pengetahuan siswa kelompok eksperimen dengan kelompok kontrol. Penerapan model pembelajaran Auditory, Intellectually, Repetition berbasis Brainstorming ini dapat menumbuhkan rasa percaya diri siswa. Pembelajaran tidak akan membosankan karena setiap siswa mampu mengemukakan pendapatnya tanpa harus takut salah yang membuat siswa belajar lebih semangat, lebih antusias dan aktif sehingga membuat kompetensi pengetahuan IPS menjadi lebih tinggi, jika dibandingkan dengan hasil penelitian yang dibelajarkan secara konvensional, siswa cenderung cepat bosan dalam mengikuti proses pembelajaran. Dalam pembelajaran konvensional siswa kurang mampu aktif dan mengemukakan pendapatnya secara lisan, sehingga ide-ide yang dimiliki siswa tidak dapat didiskusikan di dalam kelas. Siswa cenderung pasif dan kurang termotivasi dan cenderung menerima materi dari guru tanpa berani mengeluarkan pendapatnya.

Perbedaan cara pembelajaran antara pembelajaran dengan model pembelajaran Auditory, Intellectually, Repetition berbasis Brainstorming dan model pembelajaran konvensional tentunya memberikan dampak yang berbeda terhadap kompetensi siswa. Model pembelajaran Auditory, Intellectually, Repetition berbasis Brainstorming memberikan pengalaman langsung pada siswa dan menjadikan suasana belajar yang menyenangkan dan bermakna.

\section{Simpulan dan Saran}

Berdasarkan hasil analisis membuktikan terdapat perbedaan yang signifikan kompetensi pengetahuan IPS kelompok siswa yang dibelajarkan melalui model pembelajaran Auditory, Intellectually, Repetition berbasis Brainstorming dengan kelompok siswa yang dibelajarkan secara konvensional pada siswa kelas IV SD Gugus Letkol Wisnu tahun pelajaran 2018/2019. Hal ini terbukti dari rata-rata GSn kompetensi pengetahuan IPS siswa kelompok eksperimen $\overline{X_{1}}=0,664>\overline{X_{2}}=0,562$ rata-rata GSn kompetensi pengetahuan IPS kelompok kontrol, sehingga dapat disimpulkan bahwa model pembelajaran Auditory, Intellectually, Repetition berbasis Brainstorming berpengaruh terhadap kompetensi pengetahuan IPS siswa kelas IV SD Gugus Letkol Wisnu Tahun Pelajaran 2018/2019.

Berdasarkan hasil penelitian, adapun saran yang disampaikan kepada kepada guru agar dapat digunakan sebagai alternatif dalam pembelajaran di sekolah, sehingga dapat menciptkan suasana pembelajaran yang lebih aktif dan menyenangkan. Kegiatan pembelajaran pun menjadi lebih inovatif dan variatif karena dapat menggunakan model pembelajaran yang sesuai Kurikulum 2013. Salah satu model pembelajaran yang dapat disarankan, yaitu model pembelajaran Auditory, Intellectually, Repetition berbasis Brainstorming. Kepada kepala sekolah dapat menjadi masukan untuk meningkatkan kompetensi peserta didik dalam proses pembelajaran yang optimal. Dan kepada Peneliti Lain, disarankan agar hasil penelitian ini dapat digunakan sebagai referensi untuk melaksanakan penelitian selanjutnya.

\section{Daftar Pustaka}

Agung, A. A. G. 2014. Metodologi Penelitian Pendidikan. Yogyakarta: Aditya Media Publishing.

Arikunto, S. 2015. Dasar-Dasar Evaluasi Pendidikan. Jakarta: Bumi Aksara.

Dantes. 2017. Desain Eksperimen dan Analisis Data. Depok: Rajawali Pers.

Gunawan. 2014. Pendidikan IPS Filosofi, Konsep, dan Aplikasi. Bandung: Alfabeta. 
Huda, M. 2015. Model-Model Pengajaran dan Pembelajara.Yogyakarta: Pustaka Pelajar.

Mukrimaa, S. S. 2014. 53 Metode Belajar Dan Pembelajaran. Bandung: Universitas Pendiidikan Indonesia.

Pratiwi, Ni Lh. 2014. "Pengaruh Model Pembelajaran Problem Solving Dan Reasoning Berbasis Brainstorming Terhadap Kemampuan Berpikir Kreatif Pada Mata Pelajaran IPA". Jurnal Mimbar PGSD Universitas Pendidikan Ganesha Jurusan PGSD (Vol: 2 No: 1 Tahun 2014). https://ejournal.undiksha.ac.id/index.php/JJPGSD/article/view/863.

Rusman. 2015. Pembelajaran Tematik Terpadu. Bandung: PT RajaGrafindo.

Sani, R. A. (2013). Inovasi Pembelajaran. Jakarta: PT Bumi Aksara.

Setyosari, Punaji H. 2015. Metode Penelitian Pendidikan dan Pengembangan. Jakarta: Prenada Media Group.

Shoimin, A. (2014). 68 Model Pembelajaran Inovatif dalam Kurikulum 2013. Yogyakarta: Ar-Rzz Media.

Sugiyono. 2017. Metode Penelitian. Bandung: Alfabeta.

Susanto, Ahmad. 2014. Pengembangan Pembelajaran IPS di Sekolah Dasar. Jakarta: Prenadamedia Group.

Undang- Undang No 20 Tahun 2003 Bab 1 Pasal 3 tentang Sistem Pendidikan Nasional. 2003. Jakarta: Presiden Republik Indonesia.

Widiastuti, A.A. Pt. 2014. "Pengaruh Model Auditory Intellectualy Repetition Berbantuan Tape Recorder Terhadap Keterampilan Berbicara". Jurnal Mimbar PGSD Universitas Pensisikan Ganesha Jurusan PGSD (Vol: 2 No: 1 Tahun 2014). https://ejournal.undiksha.ac.id/index.php/JJPGSD/article/view/ 